\title{
Athens Military Command in the Last Third of the IV-III Centuries
}

\section{$\mathrm{BC}$}

\author{
Igor V. Vostrikov ${ }^{1}$ \\ ${ }^{1}$ Kazan (Volga Region) Federal University, Kazan, Russia \\ Correspondence: Igor V. Vostrikov, Kazan (Volga Region) Federal University, 420008, Kazan, Kremlyovskaya \\ Street, 18, Russia. E-mail: igor-vostrikov@bk.ru
}

Received: June 15, 2015 Accepted: June 24, 2015 Online Published: June 30, 2015

doi:10.5539/jsd.v8n7p131

URL: http://dx.doi.org/10.5539/jsd.v8n7p131

\begin{abstract}
The relevance of the studied problem is caused by a keen interest in antique military history and insufficient attention to the history of Athens and its military organization during the Hellenistic period. The aim of the article is to study Athens military command and identify the changes in the military command of the policy in the last third of the IV-III centuries BC. The major method of the research is a comparative and historical method allowing to consider the system of Athens military command and the changes in the last third of the IV-III centuries BC. It is based on the analysis of various sources. The article reveals: the structure of Athens military command, an election order of command positions, responsibilities of military leaders; the changes happening in the system of Athens military command during the defined chronological period. The results of the research can be useful in the further scientific researches connected with a military history of Athens and Ancient Greece, while developing special courses, manuals and reference books on the corresponding studies.
\end{abstract}

Keywords: military command, strategists, taksiarkh, lokhag, gipparkh, phylerkh, epistaty, Athens

\section{Introduction}

\subsection{Background}

Having a right to participate in public life, the Athenian citizen as a member of the policy, could be elected not only to an administrative post, but to a military one too, if his candidacy was approved. Candidates to military posts were elected by raising hands (Arist. Ath. Pol. 43. 1). Aristotle said that military positions could be held several times, whereas other positions could never be held more than once; one could be a member of the Council twice (Arist. Ath. Pol. 62. 3).

The fact of numerous elections to a military position was important for the policy and its armed forces. The fate of the state depended on the outcome of a military campaign. Military failures could threaten the policy. Apparently, multiple elections allowed to find out competent military people, that favorably influenced the armed forces. Besides, numerous elections to a military position, undoubtedly, provided experience and professional development of a citizen. It also opened certain perspectives and gave a chance for further career growth.

Fokion who was elected the strategist forty five times can be an indicative example (Trittle, 2014). And, as Plutarch writes, he "used to be the strategist not only more often than his contemporaries but also more often than those, who had served earlier. He never nominated himself, never evaded even if people asked him (Plut. Phoc. 8. 1-2). In due time Pericles (Plut. Per. 16) was elected the strategist fifteen times. An important detail is that the election was carried out by raising hands, not by lot that left no chance for come-and-go people. It should also be noted that under skillful command military leaders and simple soldiers got a good military training. A good military leader became a pattern. Nevertheless it is necessary to notice that political groups and the political environment of that time influenced the election of strategists. In this case candidates' professionalism could be of no crucial importance because of the existing political preferences. However an ideal system of strategists' election meant nomination of professionals.

\subsection{Status of a Problem}

The Hellenistic era is an important trend of research in modern Antique Studies. Along with Hellenism period, the armed forces of the ancient states are studied actively. But at the same time insufficient attention is given to the studies of Hellenistic Athens, and respectively to the military command of the policy. The studies of the 
military command organization in classical Athens is given primary importance in historiography (Hauvette-Benault, 1885; Badian, 1971; Pierart, 1974; Peake, 1990; Hamel, 1998; Fröhlich, 2000; Asmonti, 2006). As for the military command in the last third of the IV-III centuries BC, I. Kralli's work on the topic is of special interest (Kralli, 2006). However besides the mentioned works, the problem of the military command was touched upon in some other works devoted to military and political history of Athens. It lead to the preparation of this report. Disproportionate interest in the history of classical and Hellenistic Athens is caused by the fact that after the defeat in Lamiysky war Athens lost its leading position in the Greek world, stopped being the influential player and got under influence of Macedonia. As a result there was a decrease in military activity of Athens and a refusal from powerful armed forces.

\section{Methodological Framework}

\subsection{The Objectives of the Research}

Within the research of the military command in Athens there were considered: order of strategists' election, strategy structure, taksiarkhs and lokhags, cavalry commanders.

\subsection{The Basis of the Research}

The research relies on a number of works by antique authors and ancient Greek inscriptions. The role of epigraphy in the research of Athens military organization of the considered chronological period, and the military command in particular, is very high, as inscriptions are very often the only evidence of any phenomenon. Besides, the analysis of a large body of inscriptions allows to reveal the features of military command structure and to track the changes happening to the studied object in a certain time frame.

\section{Results and Discussions}

\subsection{Strategists' Election}

With registration of Athens military organization a certain procedure of strategists' election came into being (Pierart, 1974). An order of strategists' election in the time of Aristotle (that is in 30-20s IV century BC) is presented in "The Athenian polity" (61. 1). It says: "First of all, ten strategists are elected - it used to be one strategist from each phyle, and now - from all citizens. Thus, raising hands gives them a certain appointment: one - for goplitts, who commands them when they act in a campaign; one - for the country, and he protects it, and if a military operation begins on his territory, he wages a war there. Two strategists are appointed to Piraeus: one - to Munikhy, another - to Act. They have to take care of everything in Piraeus. Further on, one strategist is appointed for simmoriya: he makes lists of triyerarkh, arranges an exchange of property between them and conducts proceedings between them. The rest are given appointments in compliance with current circumstances".

Strategists in Athens were the top military officials. The structure of military command throughout the history of Athens witnessed some changes. At the beginning of Greek states' history the military command was in the tsar's hands. Though there is a lack of information on Athens early history, some data on military command can be found in different sources. Aristotle reports that "the first of the positions was that of the tsar's, the polemarkh and the archon. The tsar's position was the first one, it was inherited from his predecessors. The second was the polemarkh's position, because some tsars were incompetent in military science" (Arist. Ath. Pol. 3. 2). It is a very important fact as it shows that the tsar's power is shared between three elective posts. Polemarkh became responsible for the military affairs, because some tsars demonstrated incompetence in the military sphere. It proves that certain attention was paid to the selection of good military command in antiquity. Aristotle clarifies that these officials ruled whole life, and later on within only ten years (Arist. Ath. Pol. 3. 1). It turns out that with introduction of polemarkh's position (Hamel, 1998), restriction of his term in office, monopoly for participation in the military affairs came to an end. As a result an expanded circle of people could apply for the position.

The position of the strategist was first mentioned by Aristotle in the description of Drakont legislation and the political system at that time. Thus, the author points out that the publication of these laws took place under archon Aristekhm, that is approximately in 621/0 BC. At this time, as it runs in "The Athenian polity", strategists and gipparkhs were elected from the people who possessed property free from debts, no less than on a hundred min. and lawful children from a lawful wife at the age of over ten years. (Arist. Ath. Pol. 4. 2). Thus, as it is pointed by Aristotle, they were assigned by old strategists and gipparkhs (Arist. Ath. Pol. 4. 2). However, this first Aristotle's mention of a position of the strategist should be considered carefully.

In this case, when electing strategists and gipparkhs, property qualification and besides age qualification should be taken into consideration as a certain condition. Property qualification reflects an aristocratic character of society, whereas age qualification demonstrates that the applicant for a position of the strategist has certain life experience, and, apparently, some experience of military service. 
Strategists' activity was under constant control of the Council of five hundred and People's assembly (Fröhlich, 2000). In each pritaney a check of strategists' election was organized to find out whether they fulfilled their duties correctly (Arist. Ath. Pol. 61. 2).

The description of strategists' command in a fight at Marathon given by Herodotus is axiomatic. The army was headed by ten strategists (Herod. VI. 103). There was a disputable situation - whether to attack Persians or not, and only polemarkh's Callimachus opinion in the dispute was in favour of a fight (Herod. VI. 109-110).

During a campaign strategists carried out their command in turn. But at Marathon when the time of a command came, the strategists, who voted for fight, conceded it to Miltiades. It should be noted that at Marathon all Athenian goplitt militia and all ten strategists took part. Subsequently, as a rule, the limited contingent participated in military expeditions. There was no need for all ten strategists to participate in a campaign.

During Lycurgus's era strategists were elected from all groups of civil people, but in the V century BC 1 strategist was elected from each phyle (Arist. Ath. Pol. 22. 2; Plut. Cim. 8). However Aristotle doesn't explain when this procedure started. According to P. Rhodes, the principle of strategists' election from phyles came to an end shortly before writing "The Athenian polity" (Rhodes, 1981). Undoubtedly, a refusal from electing one strategist from each phyle promoted talented military leaders from a larger circle of people even more.

\subsection{Strategy Structure}

In Chapter 61 of "The Athenian polity" we see that in the time of Aristotle there was a certain specialization among strategists: strategist ruling goplitts in a campaign; strategist who was responsible for the defense of the country; two strategists for Piraeus (to Munikhiya and Act); strategist for simmoriya who made lists of triyerarkh and regulated the relations between them. Undoubtedly, in the V century BC strategists were engaged in certain military affairs connected with fleet, army and defense. But nothing is said about their specialization at that time. There were elected ten strategists who, most likely, could distribute current duties among them. However in the $30-20$ s of the IV century BC there was already a detailed specialization among strategists. And, now some strategies had a concrete specialization. During the elections strategists were elected to concrete specializations. Nothing can be said about the exact date of imposing specialization on strategists. Nor does Aristotle explains the fact. Certain assumptions can be made on the basis of epigraphic material.

The strategist of the country is first mentioned in an inscription of 352/1 BC where peripolarkh and demarkh (IG. II2. 204. 19-21) are also made mention. According to I. Kralli, the strategist's election could be connected with Athenians' loss of Orop (Kralli, 2006). As D. Auber believes, creation of a special position of the strategist of the country proves that the defense of Attica was constantly under the focus in the IV century BC, thus the researcher pays attention that, the issue of the country's protection was regularly discussed at People's assembly (Ober, 1985). As a matter of fact, according to "The Athenian polity", pritans gathered People's assembly four times each pritaney. Of all these four People's assemblies one was of special importance because the issues concerning protection of the country were discussed. It turns out that the questions connected with protection of the country were discussed at People's assembly in each pritaney. If we refer to the above-mentioned inscription of 352/1 BC, it is possible to assume that specialization of one of ten strategists already existed in the middle of the IV century BC. For example, D. Auber believes that such specialized strategy could start up from from the end of Peloponnesian war and until the end of the 50s of the IV century BC (Ober, 1985).

Later, in the III century BC, as a result of the distribution of strategist's responsibility, two strategists' positions emerged (IG. II2. 1303. 20; 1304. 12-13, 21): one, who was in control of Eleusis territory protection (he managed Eleusis, Panakt and Phyle), and the second in change of protection of the coast (IG. II2. 1302. 4-5; 1309. fr.a. 10; 1310. 3; Pouilloux, 19, 25) with responsibility for Ramnunt, Suny and Afidna (Kralli, 2006). So, for example, Epikhar, famous for the events in Hremonidov war, was a strategist on protection of the coast and was celebrated in an inscription from Ramnunt (Petrakos. II. 3. F. 1.1. 5-6). Definitely, such division of strategies had to promote a more effective protection of Attica's territory in the face of frequent threats of invasion.

The position of goplitts' strategist is mentioned only in the first quarter of the III century BC, in an inscription of 276/5 BC (IG. II2. 682). In particular, the document devoted to famous Athenian Fedr, lists all his military appointments, including that of a position of goplitts'strategist. As it appears from the document, he was elected at archon Kimon administration (сткк. 30-32), and then again at archon Xenophon government (сткк. 40-45). As the names of eponym archons are mentioned in the inscription, it turns out that Fedr held a position of goplitts' strategist in 288/7 and 287/6 BC.

The called document actually is the first epigraphic evidence of a position of goplitys' strategist. However, if we refer Aristotle, such specialization already existed in the 30-20s of the IV century BC or, perhaps, was established 
at this time. In this regard it turns out that during Lamiysky war goplitts' strategist, commanding the army in the campaign had to be come into full play as Athenians conducted military operations outside Attica. However the brevity of written sources and extremely small number of epigraphic documents of Lamiysky war time doesn't allow to clarify the issue. For the sake of argument, Leosfen, commanding the Athenian forces consisting of citizens and mercenaries could be goplitts' strategist, as he ran the expedition (Diod. XVIII. 9. 5; 11. 3). However according to Diodor (to Diod. XVII. 111. 3), Leosfen was chosen as the authorized strategist (Schmitt, 1992).

But there was no such position in the military command of Athens in the 30-20s of. BC. In Athens of earlier times it was an irregular position where the person managing a military campaign was elected (Asmonti, 2006). Therefore, either Diodor made a mistaken in designation of a position, or Athenians introduced this position for Leosfen. Except Leosfen, Antifil, who headed the army after Leosfen's death could also be goplitts' strategist. Diodor says that instead of Leosfen "Antifil, an outstanding and courageous person, and a gifted military leader became the strategist" (Diod. XVIII. 13. 6). It should be noted that if these military leaders were goplitts' strategists, than considerable groups of contractors were under their command. As it is difficult to make any assumptions, it is impossible to leave out the fact that they were simply strategists, without specialization. Subsequently, apprx. in $300 \mathrm{BC}$, as it is reported in the Oksirinkhsky papyrus, Hary, resisting to Lahar, was goplitts' strategist (Pap. Oxy. $2082=$ FGrHist. 257a. F. 1. 3-4). To fight against Celts in 279 BC Athens sent a military contingent led by strategist Kallipp (Paus. X. 20. 3-5), who, perhaps, could be goplitts' strategist commanding the army in the campaign. We can't but agree with Oliver's remark that, in the III century BC, despite a decrease in Athenians' military activity outside Attica, the position of goplitts' strategist was still valuable (Oliver, 2007). It is evident from the example of Fedr who, being goplitts'strategist, took measures to protect crops on the territory of Attica during Athenians' revolt against Macedonian presence in 287 BC (IG. II2. 682. 30-35).

The position of Piraeus strategists is mentioned in the ephebe inscriptions. Only the strategist of Piraeus is mentioned in the inscriptions of the 30s in the IV century BC (Reinmuth No. 4. 4-6; No. 7. 1-2; No. 8. 10; No. 9 . col. II. 9-10), whereas both the strategist of Piraeus and the strategist of Akty are present in the inscriptions of 324/3 (Reinmuth No. 15 a 2-3). It can testify that in the 330s there was a position of one strategist for Piraeus, and in the 320s the second strategist was also appointed (Rhodes, 1981). After Lamiysky war, due to the Macedonian garrison presence in Piraeus, up to an overthrow of Demetriya Falersky regime of in 307 BC, and later with a new occupation of Piraeus by Macedonian garrison under Demetriya Poliorket in 295 BC, (Paus. I. 25. 5; Plut. Demetr. 34) strategists to Piraeus were unlikely appointed. The strategist's position on simmoriy, apparently, is also an innovation. It is mentioned in an inscription of 325/4 (IG. II2.1629. col. A. 209-210).

The position of the contractors' elected strategist, who took care of the hired army is mentioned in 321/0 BC for the first time (IG. II2. 379. 10-13), And though contractors' strategists are sometimes mentioned in later documents (IG. II2. 682. 25), it remains vague, whether this position became constant or the elections of contractors' strategist took place when necessary. In this regard it is necessary to mention Fedr Sfettsky who became contractors' strategist three times (IG. II2. 682. 25) until the adoption of a decree in his honor (276/5 BC). As for Fedr, the document reports that after a year under archon Nikiya $(282 / 1 \mathrm{BC})$, he was twice elected a strategist on preparation (сткк. 22-23), repeatedly a strategist of the country (сткк. 24-25), and, at last, twice goplitts' strategist. Defining a special position of contractors' strategist is undoubtedly connected with an active use of the hired contingent in Athens of that time.

The strategist's position on preparation is of special interest. The decree in Fedr's honor is actually the first document where this position is mentioned, however, the information relating to Fedr's activity doesn't actually clarify his official functions: "being elected a strategist on preparation he cared perfectly and piously about everything that concerned him" (сткк. 23-24).

Strategists on preparation are also mentioned in other inscriptions (IG. II2. 831. 28-29; 840. 13-14; 841. 14; 842. 1; 2236. col. I. 101; SEG. XXXII. 169, 218; XXIV. 95; LXI. 50). However, there are some other documents which allow to throw light on the obligations of a strategist on preparation. So, some inscriptions bear a specification that a military leader's activity was limited to the city (SEG. XXXII. 318. col. I. 21-22, 90; col. II. 263; IG. II2. 2336. col. I. 85). Perhaps, it is because of the fact that this strategist managed preparatory activities in Athens in case of a possible siege.

At least, a hint on a strategist's on preparation functions can be present in Pseudo-Plutarch's messages in "Life of ten speakers". The author refers to Stratokl's decree in honor of Lycurgus: "being elected, to prepare for a war he provided a lot of weapon and throwing shells on an acropolis, equipped four hundred the grain-cleaning machine and restored shipyards first of all" (Ps. - Plut. Vit. X Or. 852 C). In other case the author quotes the Athenian decree in honor of Demokhar, prominent politician of the IV-III centuries BC, enumerating his merits: 
"construction of walls and preparation of arms, guns and obsidional cars" (Ps. - Plut. Vit. X Or. 851 E). Thus, it is possible to believe that similar measures were imposed on a strategist on preparation after the introduction of this position at the end of IV or at the beginning of the III century.

According to the epigraphic documents, after the end of Hremonidov war, Antigonus Gonat established control over the city. In the inscription of apprx. 250 BC (IG. II2. 1225. 7-9) Athenian Gerakleit, appointed the strategist of Piraeus by a tsar, is mentioned (Tracy, 2003a is marked out; 2003b). Another decree carries the information about the appointed strategist of the country and Eleusis (IG. II2. 1287. 3-5). In the document from Ramnunt (the middle of the III century BC) a strategist of the coast Apollodorus, appointed by tsar Antinog and elected by the people, is given a praise. He took a good care of the whole fortress (Poulloux is praised. 7. 2. 7-10). Taking into consideration this example, I. Kralli considers that when Antigonus appointed Apollodorus the military manager of the coast, he interfered with the valid election of the Athenian military leaders, and the Athenian people ratified this decision electing the latter to the military leader's position (Kralli, 2006). According to S. Traci, the inscription is dated $260 \mathrm{BC}$ and shows that Athenians elected a person chosen by the tsar (Tracy, 2003b). These appointments of strategists brightly illustrate the imperial control over the policy which lasted until 229 BC.

One of the Athenian decrees, mentioned above (IG. II2. 1304), reveals the state activity of Athenian Demenet, three times elected the strategist of the country to Eleusis (in 219/8, 215/4, 211/10 BC). However Demenet, as it comes from the text of the document, was repeatedly an ambassador in the Etoliysky union and also to tsar Philip "to make friendship and peace" with everyone (сткк. 4-8). Most likely, it occurred during the Allied war and Athens tried to establish friendship with all belligerent parties. Therefore Demenet had to work both on a military and a diplomatic field that can illustrate his abilities to execute state affairs. Also his activity as a strategist, both administrative and military should also be noted. Good exercise of powers - with nobody committing injustice either in the country, or in fortresses (стк. 14-17); commission of sacrifices during the holiday (сткк. 26-27); providing safety of elevsin mysteries (сткк. 27-29); protection of the country and fortresses (стк. 20, 23-24); purchase of bread and storage of stocks; granting money for clothes (сткк. 31-35) - is his achievement.

As for polemarkh's position, we see that though his position was high, military management was in hands of strategists. Herodotus (Herod. VI. 109) reports that during Marathon fight, the polemarkh, firstly, was elected by lot, and, secondly, since ancient times Athenians granted the polemarkh an equal vote with strategists.

In the times of Aristotle the polemarkh didn't play a significant role in the military sphere: he had a control over gravestone competitions in honor of the fallen in the war, his main sphere were the affairs of meteks and proksens (Arist. Ath. Pol. 58). So, D. Hammel fairly concludes (Hamel, 1998) that powers of the polemarkh could be reduced owing to the reform of arkhontat in 487/6 BC (Badian, 1971). As a result the polemarkh stopped exercising real military power, and by the end of the IV century BC the people appointed to this position performed only ceremonial military functions.

\subsection{Taksiarkhs and Lokhags}

Besides strategists ten more taksiarkhs were chosen, one from each phyle. Each of them ruled the citizens of his phyle and appointed lokhags (Arist. Ath. Pol. 61.3). Taksiarkhs obeyed the strategists and were a link between the high command and the soldiers of the phyle. The military contingent of a phyle, apparently, could be divided into smaller divisions - lokhs who were under lokhag command, appointed by the taksiarkhs. Taksiarkhs and lokhags are mentioned in the ephebic inscriptions. It turns out that lokhag was a junior commander in the Athenian army. Lokhags, as well as lochs, are poorly mentioned. According to Xenophon, in $408 \mathrm{BC}$ during the Athenian expedition to Pigela under Frasill's command, two lochs of goplitts and peltasts rushed to help their poorly of light-armed, disseminated friends. Xen. Hell. I. 2. 3). However, this evidence of Xenophon, who, in P. Rhodes's remark, could used it not technically, is the only mention of lochs in the Athenian army (Rhodes, 1981). In a battle at Tanagre Kimon's companions put his armor among the soldiers of his group (Plut. Cim. 17. 5). But, on the other hand, Aristotle's remark about lochs' appointment by taksiarkhs, and also mentioning of lokhags and taksiarkhs at the ephebic corps, copying a military structure of goplitsky militia, can indicate the existence of lochs in the Athenian army. In the same work Xenophon writes that one Athenian man Nikomakhid complains Socrates of having not been chosen a strategist though he was a lokhag and a taksiarkh having some experience of military command (Xen. Mem. III. 4. 1). Xenophon mentions taksiarkhs and lokhags in connection with military training (Xen. Mem. III. 4. 1). Polluks puts lokhags in the same group with taksiarkhs, gipparkhs, phylerkhs and strategists (Poll. Onom. VIII. 114).

Connection between lochs and dems seems quite probable, the formation of lochs was organized on an area basis, because all citizens fought together in the phyle. And citizens of dem could fight together. The idea of formation of lochs in tritiya when the military contingent of each phyle could consist of three lochs, is worth noticing. However, 
if expeditionary forces were small, the division of phyles on lochs failed, if there were few expeditionary forces, small groups of phyles were under command of lokhags, but not taksiarkhs (Secunda, 1992). It is difficult to speak about the number of lochs. In a fight at Plateyakh in 479 BC the Persian cavalry of Masistiya was counteracted by a group of 300 logads led by Olimpiodor, Lampon's son (Herod. IX. 21. 3). According to Plutarch, Aristide sends the bravest of Olimpiodor's chiefs with 300 perfect soldiers (Plut. Arist. 14. 3). According to Herodotus and Plutarch, Olimpiodor was a lokhag and, it turns out that a group of 300 logads made a loch. However, this fact about a loch seems a little ambiguous, because a military unit consisted of logads.

\subsection{Cavalry Commanders}

The cavalry commanders were also chosen. Two gipparkhs were appointed among all people, each of which commanded the cavalry contingent of five phyles (Arist. Ath. Pol. 61.3). Aristotle says that "they have the same power, as strategists over goplitts" (Arist. Ath. Pol. 61.3). In this regard it should be noted that gipparkhs commanded only the cavalry and obeyed the strategists who carried out the high command over all Athenian forces. Such subordination of gipparkhs to strategists is caused by a supporting role of a cavalry in the armed forces of the policy unlike goplitts. Further ten phylerkhs, one from a phyle, were chosen. And they, like taksiarkhs, were in control of cavalry divisions of their phyles (Arist. Ath. Pol. 61. 5). In this regard it turns out that five phylerkhs came under command of every gipparkh. Gipparkhs and phylerkhs were chosen at people's assembly. However in Athens cavalry corps, besides two gipparkhs and ten phylerkhs, there were lower rank commanders and there was no need for them to be elected at people's assembly. Junior commanders were important for well-coordinated and prompt actions of a cavalry. In the words of Xenophon (to Xen. Hipp. II. 2-7; IV. 9), junior commanders were appointed from each phyle by a gipparkh with consent of a phylerkh. And it was vital to appoint foremen out of people at a blossoming age and jealous to affairs. It turns out that foremen had to be not really young and at the same time well developed. Foremen were put in front of other cavaliers. Besides foremen the same number of older cavaliers was chosen, who were put at the end of tens.

In their turn foremen elected deputies - epistats, "following behind" who, apparently, also elected their deputies. The rider rounding out an array had to be a skilled soldier who in case of attack could support his soldiers, and head his soldiers of the division at retreat. In addition, it was convenient to transmit orders with the help of foremen and epistats. Thus, the structure of cavalry command was quite developed which is caused by a complexity of management of the cavalry contingent. I. Kralli reveals a tendency in a career of the most capable military leaders in the Hellenistic Athens: they begin their activity as a commander being a gipparkh, and then are elected to higher positions of strategists with various specialization (Kralli, 2006).

After the regime of Demetriya Falersky was overthrown in 307 BC, to demonstrate their gratitude for the release of the city Athenians created two new phyles - for Demetriad and Antigonid, which got their names in honor of the liberator of Athens Demetriya Poliorket and his father Antigone Odnoglazy (Habikht, 2003). The cavalry corps which was organized in phyles had to increase by two divisions of new phyles, and consist not of ten, but of twelve cavalry divisions and, respectively, to have twelve phylerkhs.

Document 282/1 of BC representing the Decree in honor of gipparkhs and phylerkhs is of great importance in studying the Athenian cavalry and its command in the III century BC (SEG. XXI. 525). First of all, conspicuous is the information on the number of cavaliers. According to the text of the Decree, originally it consisted of 200 riders, but at archon Nikiya the corps of riders was increased by 100, thereby having reached 300. In comparison with the period before Lamiysky war when the cavalry body consisted of one thousand people (Spence, 1993), there was a considerable reduction of a number of riders. It turns out that having three hundred riders in total, the contingent of each of twelve phyles should have only twenty five riders. When there was a total number of two hundred riders, the contingent of each phyle should have consisted of only sixteen riders. In case of a sharp reduction of riders the number of junior commanders also decreased. It is difficult to say when the reduction of riders took place. We can only conclude that it happened after Lamiysky war and before the publication of the Decree in 282/1 BC. Taking into account the political situation in the policy, we can assume that reduction of the cavalry body could happen at the end of the IV century BC. Such a sharp reduction of the cavalry proves that there was no longer need for a large number of riders. Besides the reduction of riders conducted lead to the cut of public expenditure on the cavalry (Nefedkin, 2005).

It is necessary to point out one more fact: the names of two gipparkhs and only eleven phylerkhs are listed in the decree (SEG. XXI. 525. 25-33). There is no phylerkh of Egeida phyle. G. Byyu believes that there was no candidate for a position of a phylerkh in Egeida's phyle that year and, it is possible, therefore, the law, forbidding the election of phylerkhs from all riders could be cancelled (Bugh, 1988). The law, mentioned in the decree, can also highlight it (SEG. XXI. 525. 11-14). If this interpretation is correct, it turns out that since then on, not only 
one phylerkh could be chosen from a phyle, but from all riders, as it was before (Arist. Ath. Pol. 61. 5). Here comes a question: who commanded riders of Egeida phyle if they had no phylerkh that year? Some assumptions can be made. The first: there was a person who was in a phylerkh's position, which was not approved officially. That's why at the decree there was no his name among other phylerkhs. The second: Egeida riders could be under command of some other phylerkh, along with the commanding the riders of his own phyle. The third: Egeida riders could be temporarily distributed into other phyles. Being a commander of two phyles, though rather alleviating by their relatively small number, after all was difficult. Distribution of riders into other phyles meant disbandment of the cavalry contingent of Egeida phyle as a fighting unit. It turned out that actually there were no Egeida representatives in the cavalry corps unlike other eleven phyles. It could affect prestige of the phyle in the policy. The first variant seems the most probable because the cavalry corps relied on the equal participation of riders from all phyles under command of phylerkhs.

\section{Conclusion}

Owing to the specific features of a social system of the policy, top military positions in Athens were elective, with a chance of numerous election. To increase the effectiveness of the military command system important changes took place by $30-20$ s of the IV century BC: since that time strategists were elected from all citizens and their specialization was introduced at the stage of their election by people's assembly. Further transformations in the strategy system were caused by military needs and political situation. When ancient Athenians refused from an active foreign policy, their military activity was concentrated on the protection of the Attica territory, which became evident in the changes of the strategy system in the first half of the III century BC. In the late eighties of the III century BC, the order filarkh election was changed. According to the new rules they could be elected from all riders, not from each fila as it used to be. In general it is necessary to note that the system of Athens military command wasn't static. All transformations were aimed at the improvement of military command system in Athens and adaptation to the new circumstances.

\section{Acknowledgement}

The work is performed according to the Russian Government Program of Competitive Growth of Kazan Federal University.

\section{References}

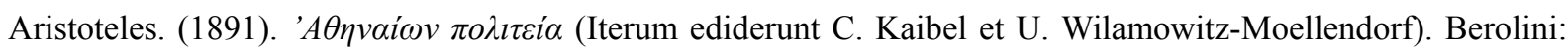
Apud Weidmannos.

Asmonti, L. (2006). The Arginusae trial, the changing role of strategoi and the relationship between demos and military leadership in late-fifth century Athens. Bulletin of the Institute of Classical Studies, 49, 1-22. http://dx.doi.org/10.1111/j.2041-5370.2006.tb00674.x

Badian, E. (1971). Archons and Strategoi. Antichthon, 5, 1-34.

Bugh, G. R. (1988). The Horsemen of Athens. Princeton: Princeton University Press. http://dx.doi.org/10.1515/9781400859757

Die Fragmente der Griechischen Historiker. Bd. I-III. (Ed. F. Jacoby). (1926-1928). Berlin: Weldmannsche Buchhandlung.

Diodorus Siculus. (1989). Library of History. Vol. I-XII. (With an English translation by C. H. Oldfather, C. L. Sherman, C. B. Welles, R. M. Geer and F. K. Walton). Cambridge, Massachusetts: Harvard University Press; L.ondon: William Heineman.

Fröhlich, P. (2000). Remarques sur la reddition de comptes de stratèges athéniens. Dike, 3, 81-111.

Hamel, D. L. (1998). Athenian Generals. Military Authority in the Classical Period. Leiden: Brill.

Hauvette-Benault, A. (1885). Les stratèges athéniens. Paris.

Herodotus. (1920-1925). The Persian Wars. In Four Volumes. Books 1-9. (With an English Translation by A. D. Godley). London: William Heinemann; New York: G. P. Putnam's Sons.

Inscriptiones Graecae. (Editio minor. Vol. I-II/III.). (1913-1924). Berlin.

Khabikht, Kh. (2003). Athens. City history in the Hellenistic era. Moscow: Scientific and publishing centre "Ladomir".

Kralli, I. (2006). Aspects of Athenian Military Command under the Antigonids (262-229 B.C.). Continuity or Change. Athenaeum, 94. 1, 543-561. 
Nefedkin, A. K. (2005). Cavalry of Hellenistic Athens. Bulletin of the St. Petersburg University, 2-3, 138-141.

Ober, J. (1985). Fortress Attica: Defense of the Athenian Land Frontier 404-322 B.C. Leiden: Brill.

Oliver, G. J. (2007). War, Food and Politics in Early Hellenistic Athens. Oxford.

Pausanias. (1926-1939). Description of Greece. Vol. I-VI. (With an English translation. by W. H. Jones). London: William Heinemann; New York: G. P. Putnam's Sons.

Peake, S. (1990). The Role of the 'Strategoi' in Athens in the 4th Century B.C.: (Doctoral dissertation). University of St. Andrews, St. Andrews, Scotland, United Kingdom.

Petrakos, V. Ch. (1999). Ho dēmos tou Ramnountos. T. II. Hoi epigraphes. Athens.

Pierart, M. (1974). À propos de l'élection des stratèges athéniens. Bulletin de correspondance hélléniques, 98(1), 125-146. http://dx.doi.org/10.3406/bch.1974.2100

Plutarchus. (1959). Plutarch's Lives. Vol. I-XI (With an English translation. by B. Perrin). Cambridge, Massachusetts: Harvard University Press; L.ondon: William Heineman LTD.

Pollux Julius. (1824). Onomasticon. Vol. 1-5 (Ed. W. Dindorf). Leipzig: Teubner.

Pouilloux, J. (1954). La Forteresse de Rhamnounte. Paris.

Pseudo-Plutarch. (1962). Biography of ten speakers. (from Greek. L. M. Gluskina). Bulletin of ancient history, 2, 238-243.

Reinmuth, O. W. (1971). The ephebic inscriptions of the fourth century B.C. Boston; Leiden; Koln: Brill.

Rhodes, P. J. (1981). A Commentary on the Aristotelian Athenaion Politeia. Oxford: Clarendo Press.

Schmitt, O. (1992). Der Lamische Krieg. Bonn: Habelt.

Sekunda, N. W. (1992). Athenian Demography and Military Streugth 338-322 B.C. The Annual of the British School at Athens, 87, 311-355. http://dx.doi.org/10.1017/S0068245400015203

Spence, I. G. (1993). The Cavalry of Classical Greece. Oxford: Clarendon Press.

Supplementum Epigraphicum Graecum. (1923-). Leiden.

Tracy, S. V. (2003a). Antigonas Gonatas, King of Athens. In O. Palagia, \& S. Tracy (Eds.), The Macedonians in Athens. Proceedings of an International Conference held at the University of Athens, May 24-26, 2001 (pp. 56-60). Exeter: Oxbow books.

Tracy, S. V. (2003b). Athens and Macedon: Attic Letter-Cutters of 300-229 B.C. Berkeley; Los Angeles; London: University of California Press.

Trittle, L. (2014). Phocion the Good. Routledge.

Xenophon. (1946). On the cavalry commander. In T. E. Page, E. Capps, W. H. D. Rouse, L. A. Post, \& E. H. Warmington (Eds.), Xenophon. Scripta Minora (With an English translation by E. C. Marchant). (pp. 233-294). Cambridge, Massachusetts: Harvard University Press; L.ondon: William Heineman LTD.

Xenophon. (1961). Hellenica, Books 1-5. (With an English translation by Carleton L. Brownson). Cambridge, Massachusetts: Harvard University Press; L.ondon: William Heineman LTD.

Xenophon. (1997). Memorabilia. Oeconomicus. Symposium. Apology. (With an English translation. by E. C. Marchant, O. J. Todd). Cambridge, Massachusetts: Harvard University Press; L.ondon, England.

\section{Copyrights}

Copyright for this article is retained by the author(s), with first publication rights granted to the journal.

This is an open-access article distributed under the terms and conditions of the Creative Commons Attribution license (http://creativecommons.org/licenses/by/3.0/). 